\title{
Factors Related toThe Incidence of Nutritional Deficiencies in Children Under Five
}

\author{
Siti Gabena Siregar \\ Poltekkes Kemenkes Medan \\ e-mail: gabenasiti@gmail.com
}

\begin{abstract}
The nutritional deficiencies cases for under five can be caused by poverty, food supply, poor environmental sanitation, lack of community knowledge about nutrition, and the existence of poor areas of iodine and infectious diseases. The result of weighing at posyandu of Sekip Village, Lubuk Pakam Subdistrict, Deli Serdang Regency, shows that of the 1,712 below five year-old children with the weighing coverage of 1,404 below five year-old children (82\%), 1,372 of them (80.1\%) had good nutrition, 339 of them (19.8\%) had nutritional deficiency, and 1 of them $(0.06 \%)$ had malnutrition. Based on this, it is necessary to analyze the relationship between the characteristics and parenting factors for children to the amount of malnutrition in children in the area.The moethod used in this study is a survey with a cross sectional approach. The population in this study were mothers with under fives as many as 1,712 people and a total sample of 100 people. Data collection through questionnaires. The method of data analysis with univariate and bivariate using the chi square statistical test at a significance level of 5\%.The results showed that there was a relationship between maternal characteristics of education, income, knowledge, and parenting factors about the practice of feeding and health practices with the incidence of malnutrition in under five. The conclusion of the study is that under five experiencing malnutrition are caused by education, income and low knowledge and poor diet and health patterns.
\end{abstract}

KEYWORDS:nutritional deficiencies, children under five, Sumatera Utara

\begin{abstract}
ABSTRAK
Kasus kekurangan gizi untuk balita dapat disebabkan oleh kemiskinan, persediaan makanan, sanitasi lingkungan yang buruk, kurangnya pengetahuan masyarakat tentang nutrisi, daerah dengan kekurangan iodium dan penyakit menular. Hasil penimbangan di posyandu Desa Sekip, Kecamatan Lubuk Pakam, Kabupaten Deli Serdang, menunjukkan bahwa dari 1.712 anak di bawah lima tahun dengan cakupan berat 1.404 anak di bawah lima tahun (82\%), 1.372 di antaranya ( $80,1 \%)$ memiliki gizi yang baik, 339 di antaranya $(19,8 \%)$ memiliki kekurangan gizi, dan 1 di antaranya $(0,06 \%)$ memiliki kekurangan gizi.. Berdasarkan hal ini, perlu dilakukan analisis hubungan antara karakteristik dan faktor pengasuhan dengan jumlah gizi buruk pada anak-anak di daerah tersebut. Metode yang digunakan dalam penelitian ini adalah survei dengan pendekatan cross sectional. Populasi dalam penelitian ini adalah ibu dengan balita sebanyak 1.712 orang dan sampel total 100 orang. Pengumpulan data melalui kuesioner. Metode analisis data dengan univariat dan bivariat menggunakan uji statistik chi square pada taraf signifikansi 5\%. Hasil penelitian menunjukkan bahwa ada hubungan antara karakteristik ibu pendidikan, pendapatan, pengetahuan, dan faktor pengasuhan tentang praktik pemberian makan dan praktik kesehatan dengan kejadian gizi buruk pada balita. Kesimpulan dari penelitian ini adalah bahwa balita yang mengalami kekurangan gizi disebabkan oleh pendidikan, pendapatan dan pengetahuan yang rendah serta pola makan dan pola kesehatan yang buruk.
\end{abstract}

Kata Kunci: kekurangan gizi, balita, Sumatera Utara 


\section{INTRODUCTION}

Nutritional problems are one of the main problems of public health in the world, especially for under fives because they are closely related to general health indicators such as increased morbidity and mortality. Poor nutrition also affects growth, intellectual development and productivity. Under fives who are malnourished will grow short and experience disorders of brain growth and development that affect low levels of intelligence(1-3).

The death of children under 5 years reached 6.6 million in 2012 or nearly 18,000 people every day. The risk of a child dying before reaching the age of 5 for the European region is 12 per 1000 live births and in Africa about 8 times higher than the European region (95 per 1000 live births). While the Asia region, especially South Asia reaches 50 per 1000 live births(4-6).

Under-five mortality rates in Indonesia are still relatively high compared to other member countries of the Association of South East Asia Nations (ASEAN). Based on the Indonesian Health Data Profile in 2012, the Under five Mortality Rate (AKABA) in Indonesia is 40 per 1,000 live births, still higher than Malaysia, which is 6.5 per 1,000 live births, the Philippines is 25.4 per 1,000 live births and Thailand 12, 3 per 1,000 live births(7-9).

Based on data from the North Sumatra Provincial Health Office in 2015 there were 1,565,036 children under five. There are 4 (four) main nutritional problems in North Sumatra Province, namely macro nutrition problems, especially under fives with Protein Energy Deficiency (KEP), micronutrient nutrition problems, especially Vitamin A Deficiency (KVA), Iron Nutrition Anemia (AGB) and Iodine Deficiency Disorders ( GAKY). The prevalence of malnutrition and underweight children in North Sumatra Province has decreased, malnutrition cases in 2014 as many as 1,196 cases decreased to 1,152 in 2015. Likewise, malnutrition cases decreased in 2012 by $3.7 \%$ and increased to $4.1 \% 2013$ (North Sumatra Provincial Government, 2014). Data from the Deli Serdang District Health Office in 2015 amounted to 221,854 under-fives with $22 \%$ less nutritional status. Seeing this condition, it is appropriate that the problem of under-nutrition status is still a top priority in supporting community health development in the area.

The purpose of this study was to determine the relationship between maternal characteristics and nutritional conditions in infants or children under five years old.

\section{METHODS}

This type of research is a survey with a cross sectional approach carried out in Sekip Village, Lubuk Pakam District, Deli Serdang Regency. The population in this study was under fives in Sekip Village, Lubuk Pakam Subdistrict, Deli Serdang Regency in 2016 with 1,712 people. The sampling technique is based on a gradual cluster technique, which is to determine the hamlet as a cluster in the first stage. 
The next stage determines the households that are used as sample members(10). the number of samples used can be seen in table 1 .

Table 1. Calculation of sample

\begin{tabular}{|c|c|c|c|c|}
\hline No. & Village name & $\begin{array}{l}\text { number of } \\
\text { households }\end{array}$ & Calculation & Sample \\
\hline 1. & Sempurna & 160 & $(160 / 825) \times 100$ & 19 \\
\hline 2. & Pembangunan I & 170 & $(170 / 825) \times 100$ & 21 \\
\hline 3. & Bakti I & 150 & $(150 / 825) \times 100$ & 18 \\
\hline 4. & Ampera Selatan & 170 & $(170 / 825) \times 100$ & 21 \\
\hline 5. & Sadar Barat & 175 & $(175 / 825) \times 100$ & 21 \\
\hline & Jumlah & 825 & & 100 \\
\hline
\end{tabular}

Data collection is based on the type of research data, namely primary data and secondary data. Primary data in this study included maternal characteristics (age, education, occupation and knowledge), parenting (feeding practices and health practices). Secondary data in this study are the results of weighing under fives registered in integrated service posts (Posyandu??). The variables in this study are independent variables in the form of maternal characteristics (education, opinions and knowledge), and the dependent variable is parenting (feeding practices and health practices).

The variable measurement method in this study is to observe the relationship between research variables as in Table 2.

Table 2. Measurement of research variables

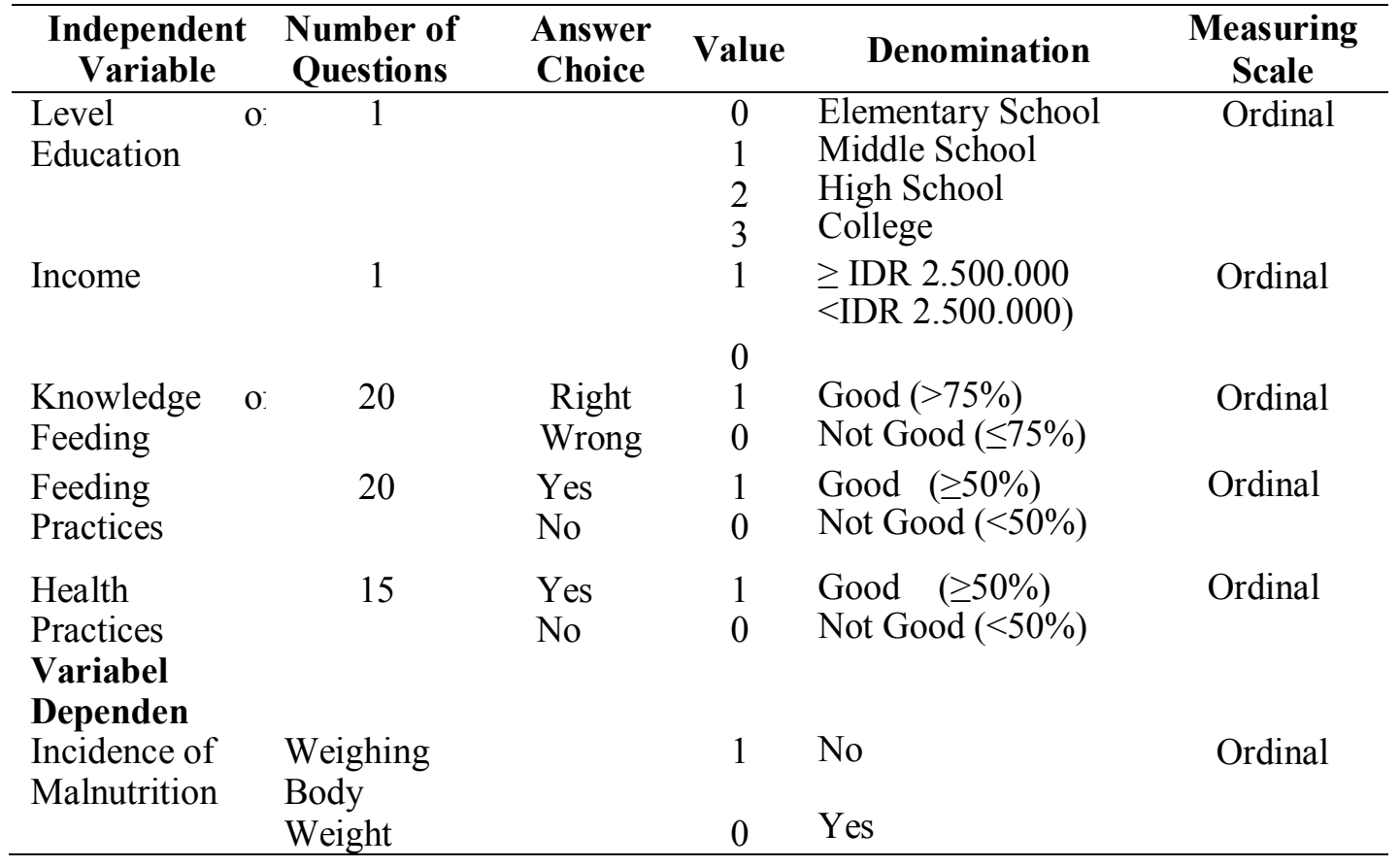


The data obtained will be analyzed using the univariate method to explain and describe all the independent variables that will be presented in the frequency distribution table. Bivariate analysis was performed to analyze the relationship of independent variables with dependent variables using the chi square correlation test using a significance level of $5 \%(\alpha=0.05)$.

\section{RESULTS}

\section{Characteristics of Mother and Under five}

The results of data collection on the characteristics of mothers and children under five who live in Sekip Village, Lubuk Pakam District, Deli Serdang Regency in 2017 can be seen in tables 3 and 4.

Tabel 3.Matternal Characteristics

\begin{tabular}{|c|c|c|c|}
\hline No & Characteristics & $\mathbf{N}$ & $\%$ \\
\hline \multicolumn{4}{|c|}{ Age (years old) } \\
\hline 1. & $<25$ & 4 & 4.0 \\
\hline 2. & $25-35$ & 60 & 60.0 \\
\hline 3. & $>35$ & 36 & 36.0 \\
\hline \multicolumn{4}{|c|}{ Level of Education } \\
\hline 1. & Elementary School & 6 & 6.0 \\
\hline 2. & Middle School & 26 & 26.0 \\
\hline 3. & High School & 64 & 64.0 \\
\hline 4. & College & 4 & 4.0 \\
\hline \multicolumn{4}{|c|}{ Type of Work } \\
\hline 1. & Government Employees & 2 & 2.0 \\
\hline 2. & Private Employees & 10 & 10.0 \\
\hline 3. & Entrepreneur & 7 & 7.0 \\
\hline 4. & Housewife & 60 & 60.0 \\
\hline 5. & Farmer & 21 & 21.0 \\
\hline \multicolumn{4}{|c|}{ Income } \\
\hline & $\geq$ IDR 2.5 Million & 42 & 42.0 \\
\hline & <IDR 2.5 Million & 58 & 58.0 \\
\hline & $\begin{array}{r}\text { Total } \\
\end{array}$ & 100 & $\mathbf{1 0 0 . 0}$ \\
\hline
\end{tabular}

Tabel 4.Under five Characteristics

\begin{tabular}{llccc}
\hline No & \multicolumn{2}{c}{ Under five Characteristics } & N & $\%$ \\
\hline \multicolumn{3}{c}{ Age (Months old) } \\
1. & $13-36$ & 51 & 51.0 \\
2. & $37-60$ & Gender & 49 & 49.0 \\
& & & & \\
1. & Girl & & 62 & 62,0 \\
2. & Boy & & 38 & 38,0 \\
\hline
\end{tabular}


The frequency of malnutrition in children under five, the level of knowledge and practice of mothers in under five feeding, and health practices in infants can be seen in table 5 .

Table 5. The number of malnutrition, the level of knowledge and practice of mothers in providing nutrition and health practices in under five

\begin{tabular}{|l|l|l|l|}
\hline \multirow{2}{*}{ No } & \multicolumn{1}{|c|}{ Profil } & \multicolumn{2}{c|}{ Value (\%) } \\
\cline { 3 - 4 } & & Yes & No \\
\hline 1 & Malnutrition in under fives & 34 & 66 \\
\hline 2 & Mother's level of knowledge is good at providing nutrition & 53 & 47 \\
\hline 3 & Mother's practice is good at providing nutrition & 44 & 56 \\
\hline 4 & Maternal health practices are good at providing nutrition & 46 & 54 \\
\hline
\end{tabular}

The relationship between education level and total income to the incidence of under fivemalnutrition can be seen in Table 6.

Tabel 6. The relationship between education level and total income to the incidence of malnutrition

\begin{tabular}{|l|l|c|c|}
\hline No & Level of Education & Total Sample & $\begin{array}{l}\text { Malnutrition } \\
\text { Incidence (\%) }\end{array}$ \\
\hline 1 & Elementary School & 6 & 83.3 \\
\hline 2 & Middle School & 26 & 46.2 \\
\hline 3 & High School & 64 & 25.0 \\
\hline 4 & College & 4 & 25.0 \\
\hline No & Total Income & Total Sample & $\begin{array}{l}\text { Malnutrition } \\
\text { Incidence }\end{array}$ \\
\hline & $\geq$ IDR 2,500,000.00 & 42 & 16,7 \\
\hline & $<$ IDR 2,500,500.00 & 58 & 46,6 \\
\hline
\end{tabular}

The results of the study that show the relationship between the level of knowledge of mothers in food descriptions for children under five, the feeding practices and the practice of seeing children under five on the incidence of malnutrition can be seen in table 7. 
Table 7. The relationship between the level of knowledge of mothers, pratices in feeding and health for under five on the malnutrition incidence

\begin{tabular}{|c|c|c|c|c|}
\hline \multirow[t]{2}{*}{ No } & \multirow[t]{2}{*}{ Description } & \multicolumn{2}{|c|}{$\begin{array}{c}\text { The Malnutrition Incidence based } \\
\text { on Parameters }\end{array}$} & \multirow[t]{2}{*}{ Total Sample } \\
\hline & & Good & Not Good & \\
\hline 1 & Knowledge of Feeding & $13.2 \%$ & $57.4 \%$ & 100 \\
\hline 2 & Feeding Practices & $11.4 \%$ & $51.8 \%$ & 100 \\
\hline 3 & Health Practices & $13.0 \%$ & $51.9 \%$ & 100 \\
\hline
\end{tabular}

Mana hasil uji statistiknya?

Penulisan tabel hasil tidak lazim

\section{DISCUSSION}

Health status is one aspect of parenting that can affect children's nutritional status towards improving. Health status is things that are done to maintain the nutritional status of children, keep away and avoid diseases and that can cause a decline in the state of health of children. This health status includes the treatment of diseases in children when the child is suffering from illness and preventive measures against the disease so that the child does not get an illness. Children's health status can be taken by paying attention to the state of nutrition, the completeness of the immunization, the child's personal hygiene and the environment in which the child is located, and the mother's efforts in seeking treatment for children when the child is sick. If the child is sick, the mother should take him to the place of health services such as hospitals, clinics, health centers and others(11,12).

Parenting about health is very important for children's development. The better the health management carried out by the mother, the better the pattern of family health. So that in an effort to protect children from disease because it will affect the family nutritional status(13-15).

Mothers who do not implement good health practices in the case of mothers not bathing their children 3 times a day, brushing their teeth, not always throwing garbage into a garbage dump and burning it to avoid contamination and clean children's beds. The low sanitation and cleanliness of the environment also triggers a disturbance in the digestive tract, which makes energy for growth diverted to the body's 
resistance to infection. A study found that the more often a child has diarrhea, the greater the likelihood of stunting(16-20).

\section{CONCLUSION AND RECOMMENDATION}

The incidence of malnutrition in children under five is as much as $34 \%$, generally aged 37 $<60$ months occur in families with incomes below Rp. 2.5 million. The relationship between the level of education, family income, mother's knowledge and practice in providing nutrition to infants, and health practices to the incidence of malnutrition in infants in Sekip Village, Deli Serdang Regency, Sumatera Utara.

The results of the study need to be further developed by examining the nutritional status of less / more or adding variable items from this study to be able to find out what can be done to avoid children under five not experiencing the incidence of undernutrition in growth and development.

\section{REFERENCES}

1. Meikawati W, Hersoelistyorini W. Hubungan Karakteristik Ibu dan Tingkat Sosial Ekonomi Keluarga terhadap Kasus Gizi Buruk pada Balita di Kelurahan Tandang Kecamatan Tembalang. In: PROSIDING SEMINAR NASIONAL \& INTERNASIONAL. 2008.

2. Sigulem DM, Morais TB, Cuppari L, Franceschini SCC, Priore SE, Camargo KG, et al. A Webbased distance education course in nutrition in public health: case study. J Med Internet Res. 2001;3(2):e16.

3. Tulchinsky TH. Micronutrient deficiency conditions: global health issues. Public Health Rev. 2010;32(1):243.

4. Mathews TJ, MacDorman MF, Thoma ME. Infant mortality statistics from the 2013 period linked birth/infant death data set. 2015;

5. Woodruff TJ, Grillo J, Schoendorf KC. The relationship between selected causes of postneonatal infant mortality and particulate air pollution in the United States. Environ Health Perspect. 1997;105(6):608-12.

6. Lawn JE, Blencowe H, Darmstadt GL, Bhutta ZA. Beyond newborn survival: the world you are born into determines your risk of disability-free survival. Nature Publishing Group; 2013.

7. Titaley CR, Dibley MJ, Agho K, Roberts CL, Hall J. Determinants of neonatal mortality in Indonesia. BMC Public Health. 2008;8(1):232. 
8. Semba RD, Kraemer K, Sun K, De Pee S, Akhter N, Moench-Pfanner R, et al. Relationship of the presence of a household improved latrine with diarrhea and under-five child mortality in Indonesia. Am J Trop Med Hyg. 2011;84(3):443-50.

9. Kosen S, Gunawan S. Health services in Indonesia. Med J Aust. 1996;165(11-12):641.

10. Mann CJ. Observational research methods. Research design II: cohort, cross sectional, and casecontrol studies. Emerg Med J. 2003;20(1):54-60.

11. Rampersaud GC, Pereira MA, Girard BL, Adams J, Metzl JD. Breakfast habits, nutritional status, body weight, and academic performance in children and adolescents. J Am Diet Assoc. 2005;105(5):743-60.

12. Ventura AK, Birch LL. Does parenting affect children's eating and weight status? Int J Behav Nutr Phys Act. 2008;5(1):15.

13. Young KT, Davis K, Schoen C, Parker S. Listening to parents: a national survey of parents with young children. Arch Pediatr Adolesc Med. 1998;152(3):255-62.

14. Casey PH, Szeto K, Lensing S, Bogle M, Weber J. Children in food-insufficient, low-income families: prevalence, health, and nutrition status. Arch Pediatr Adolesc Med. 2001;155(4):50814.

15. Alaimo K, Olson CM, Frongillo EA. Low family income and food insufficiency in relation to overweight in US children: is there a paradox? Arch Pediatr Adolesc Med. 2001;155(10):11617.

16. Rah JH, Akhter N, Semba RD, De Pee S, Bloem MW, Campbell AA, et al. Low dietary diversity is a predictor of child stunting in rural Bangladesh. Eur J Clin Nutr. 2010;64(12):1393.

17. Teshome B, Kogi-Makau W, Getahun Z, Taye G. Magnitude and determinants of stunting in children underfive years of age in food surplus region of Ethiopia: the case of west gojam zone. Ethiop J Heal Dev. 2009;23(2).

18. Stevens J, Iida H, Ingersoll G. Implementing an oral health program in a group prenatal practice. J Obstet Gynecol Neonatal Nurs. 2007;36(6):581-91.

19. Lauritzen C, Reedtz C, Van Doesum KTM, Martinussen M. Implementing new routines in adult 
mental health care to identify and support children of mentally ill parents. BMC Health Serv Res. 2014;14(1):58.

20. Zuckerman B, Parker S, Kaplan-Sanoff M, Augustyn M, Barth MC. Healthy Steps: a case study of innovation in pediatric practice. Pediatrics. 2004;114(3):820-6. 